\title{
Local Communities in Afghanistan Can Play Crucial Role in Improving Security
}

\author{
FOR RELEASE
}

Monday

July 26, 2010

The Afghan government and NATO can improve security in Afghanistan by leveraging traditional policing institutions in rural villages and mobilizing the population against insurgents, according to a new RAND Corporation study.

However, action needs to happen quickly to take advantage of a growing amount of local resistance against the Taliban across Afghanistan.

Security in Afghanistan historically has required a combination of top-down efforts from the central government and bottom-up efforts from local communities. Since 2001, U.S. and broader international efforts have focused on establishing security solely from the top-down through the Afghan national security forces and other central government institutions, with poor results.

"Local security forces are a critical component of security efforts, particularly in rural areas of the country," said Seth G. Jones, co-author of the study and a senior political scientist with RAND, a nonprofit research organization. "Small and defensive 'community watch' units under the control of local shuras (councils) have been a key part of stability, such as during the Musahiban dynasty from 1929-1978. But developing a successful bottom-up strategy requires building competent national army and police forces that retain the balance of power."

"Working with these local community groups also will make it easier for the Afghan government and NATO to engage in counterinsurgency operations against the Taliban and other insurgent groups," said Arturo Munoz, co-author of the study and a senior political scientist with RAND. "Insurgencies operate best in rural areas where the central government's role isn't as strong, and where the insurgents can try to win the population over to their side."

Public opinion polls and other data indicate that the Taliban has failed to establish significant support among Afghans, providing an opportunity for the Afghan government and NATO forces to better engage local communities, Jones said. A local defense program can encourage local residents to defend their community from fanatics trying to impose an extremist ideology.

Jones and Munoz compiled a list of nearly two dozen tribal and other local policing cases since 1880 and assessed their effectiveness. They also conducted meetings with dozens of tribal and community leaders across Afghanistan, particularly in the west, south and east. In addition, the study delves into anthropological work on tribal and community dynamics to better understand how a local defense initiative could be implemented. 
Security is a top-level concern for most Afghanis, with nearly 50 percent of Afghans reporting that security from crime and violence is "somewhat" or "very" bad. Current efforts to secure the area through top-down efforts only have largely failed because there are not enough national forces to protect the population, particularly in rural areas and because the Afghan national forces, particularly the Afghan National Police, "remain incompetent, ill-prepared and unpopular," according to the study.

Based on their findings, Jones and Munoz recommend the Afghan government and NATO forces move quickly to establish a more effective bottom-up strategy to complement existing top-down efforts.

Power in the rural parts of Afghanistan remains local and individuals identify themselves by multiple and often competing identities based on their tribe, sub-tribe, clan, qawm or community. A range of traditional institutions, such as arbakai and chalweshtai-small community unitshave historically been used to police their communities.

These groups are not militias but are defensive, village-level policing forces under the control of local shuras and jirgas. A jirga is a council established on a temporary basis to address specific issues, while a shura is a more permanent, consultative council.

Resistance to the Taliban and other insurgents needs to come from the grassroots, Munoz said. One place to start is by identifying communities where the locals have already resisted the Taliban or other groups or have asked the Afghan government or NATO for assistance in resisting insurgents. Many of these communities already have traditional policing structures.

Not every community will want a permanent central government presence in their villages, so the central government will have to tread carefully. But the Afghan government should take the lead in training, mentoring, vetting and overseeing local defense forces.

But while these local security forces can play a vital role, Jones and Munoz recommend that they be kept small, defensive and under the immediate control of jirgas and shuras. They also recommend establishing a Quick Reaction Force made up of Afghan and NATO forces to support local defense forces when they come under attack.

The study suggests that the central government provide development aid that benefits the communities, particularly in the area of job creation. However, local defense forces traditionally have not been paid, and Jones and Munoz recommend maintaining that tradition. Community service and not personal gain should remain the motivating factor for these groups.

The study also addresses concerns some critics have raised about whether engaging local forces will lead to more violence in the countryside, strengthen local warlords, weaken central government forces, and undermine efforts to disarm and demobilize armed groups in Afghanistan. Jones and Munoz contend that with careful implementation, a local defense initiative should be able to minimize the risks and maximize the benefits of leveraging local security forces. 
The study, "Afghanistan's Local War: Building Local Defense Forces," can be found at www.rand.org.

Research for the study was sponsored by Marine Corps Intelligence Activity within the Intelligence Policy Center of the RAND National Defense Research Institute, a federally funded research and development center sponsored by the Office of the Secretary of Defense, the Joint Staff, the Unified Combatant Commands, the Navy, the Marine Corps, the defense agencies and the defense Intelligence Community.

- Share on Facebook0

- Share on Twitter

- Share on LinkedIn0

\section{About the RAND Corporation}

The RAND Corporation is a research organization that develops solutions to public policy challenges to help make communities throughout the world safer and more secure, healthier and more prosperous. 